OPEN ACCESS

Approved by:

Frontiers Editorial Office,

Frontiers Media SA, Switzerland

${ }^{*}$ Correspondence:

Naiara Ozamiz-Etxebarria

naiara.ozamiz@ehu.eus

Specialty section:

This article was submitted to

Health Psychology,

a section of the journal

Frontiers in Psychology

Received: 23 July 2020

Accepted: 29 July 2020

Published: 01 September 2020

Citation:

Ozamiz-Etxebarria N, Idoiaga Mondragon N, Dosil Santamaría M and Picaza Gorrotxategi M (2020)

Corrigendum: Psychological Symptoms During the Two Stages of

Lockdown in Response to the COVID-19 Outbreak: An Investigation in a Sample of Citizens in Northern Spain. Front. Psychol. 11:2116 doi: 10.3389/fpsyg.2020.02116

\section{Corrigendum: Psychological Symptoms During the Two Stages of Lockdown in Response to the COVID-19 Outbreak: An Investigation in a Sample of Citizens in Northern Spain}

\author{
Naiara Ozamiz-Etxebarria ${ }^{1 *}$, Nahia Idoiaga Mondragon ${ }^{1}$, María Dosil Santamaría ${ }^{2}$ and \\ Maitane Picaza Gorrotxategi ${ }^{3}$ \\ 1 Department of Developmental and Educational Psychology, University of the Basque Country UPV/EHU, Leioa, Spain, \\ ${ }^{2}$ Department of Research and Diagnostic Methods in Education, University of the Basque Country UPVIEHU, Leioa, Spain, \\ ${ }^{3}$ Department of Didactics and School Organization, University of the Basque Country UPVIEHU, Leioa, Spain
}

Keywords: stress, anxiety, depression, lockdown, CovID-19

\section{A Corrigendum on}

Psychological Symptoms During the Two Stages of Lockdown in Response to the COVID-19 Outbreak: An Investigation in a Sample of Citizens in Northern Spain by Ozamiz-Etxebarria, N., Idoiaga Mondragon, N., Dosil Santamaría, M., and Picaza Gorrotxategi, M. (2020). Front. Psychol. 11:1491. doi: 10.3389/fpsyg.2020.01491

In the original article, we neglected to include the funder KideOn Research Group of the Basque Government, Ref.: IT1342-19 (A category).

The authors apologize for this error and state that this does not change the scientific conclusions of the article in any way. The original article has been updated.

Copyright $\odot 2020$ Ozamiz-Etxebarria, Idoiaga Mondragon, Dosil Santamaría and Picaza Gorrotxategi. This is an open-access article distributed under the terms of the Creative Commons Attribution License (CC BY). The use, distribution or reproduction in other forums is permitted, provided the original author(s) and the copyright owner(s) are credited and that the original publication in this journal is cited, in accordance with accepted academic practice. No use, distribution or reproduction is permitted which does not comply with these terms. 